\title{
上流下層加湿による積雲対流の予測実験 NUMERICAL PREDICTION EXPERIMENT OF CUMULUS CONVECTION BY UPSTREAM LOWER-LEVEL HUMIDIFICATION
}

\author{
若月泰孝 ${ }^{1}$ \\ Yasutaka WAKAZUKI \\ 1正会員 理博 筑波大学 助教（テ305-8577 茨城県つくば市天王台1-1-1）
}

\begin{abstract}
A short-term precipitation prediction (nowcast) method was developed by using upstream low-level humidification (ULH) in a cloud-resolving atmospheric model simulation. The ULH plays a role in the approximated adjoint calculation for time integration of four-dimensional variational data assimilation. This method was applied to a heavy rainfall event observed in the Kanto Plain on September 2, 2013. The heavy rainfall caused by a few cumulonimbus clouds was predicted by the ULH well before 30 minutes. The upstream advection period of 20 minutes was appropriate for more accurate prediction. The predicted cumulonimbus cloud included a large vertical vorticity that seems to have been associated with the observed tornado.
\end{abstract}

Key Words : Short-term precipitation prediction, Cloud-resolving model, Radar data

\section{1. はじめに}

積乱雲に伴う豪雨は，ナウキャストにより予測計算が 実施されている．基本的には，レーダエコーの移動べク トル推定に基づく，時間外挿による予測である(斉藤ほ $か^{1)}$; 加藤ほか22). これに, 山岳に伴う降水域の停滞効 果，経験的発生や消滅などの技術的工夫が組み込まれる (吉野ほか ${ }^{3)}$; 飯田ほが $\left.{ }^{4}\right)$ 。 また，全国のX-bandマルチパ ラメータレーダによる高解像度降雨分布データの利用に よって，その推定精度は近年格段に高くなってきている. 気象庁では，高解像度降水ナウキャストを2014年より運 用し始め, 降水 3 次元分布の時間補外之鉛直1次元対流乇 デルを併用し降水を立体的に予測するスキームを導入す ることによって, 近未来の降水の予測精度向上に貢献し た (気象庁) $)$.

一方, 非静力学雲解像大気モデルのシミュレーション による予測（以下，物理的予測）は，モデルが表現する 降水の量的な再現精度が必ずしも高くないため, 統計的 な手法による補正が必要になると考えられるものの，積 雲対流の生成・発達・消滅などの進化を再現できるポテ ンシャルを持っていることから, 物理的予測の研究の必 要性は高い. また, 物理的予測は, 降水の水平分布のみ を予測するのではなく, 大気の3次元の熱力学的構造を 予測することが可能になるので，豪雨だけでなく突風な どの気象災害の予測にも活用できる可能性がある。しか
し，物理的予測は，積雲対流の内部構造に関する情報が， シミュレーションの初期值に適切に組み込まれていない ために，2時間程度先までの降水の予測精度は必ずしも 期待されるほど高いとは言えない，観測データは「デー 夕同化」によって，前の時間からの予測と最適条件で結 合され，もつともらしい初期值が作成されるが，そこに 積雲対流の構造が十分な精度で含まれていないというこ とを意味している.

豪雨災害が顕著になる昨今，20分〜2時間先の降水の 予測精度の向上が，期待されるようになってきた。 通常, 時間外挿予測と物理的予測のブレンディングによって降 水予測のスコアを向上させる手法が用いられる (Kober et al. $\left.{ }^{6}\right)$ ） ここに, 積雲対流の構造をシミュレーションの 初期值に組み込んだ物理的予測が加わり（詳細は2章で 解説），3種類の予測のブレンディングを行うことがで きれば，減災に結びつくより有益な予測情報を提供でき るようになるはずである.

本研究では, レーダ観測によって得られた積雲対流に 伴う降水の情報を，物理的予測に組み込むための方法に ついて研究し, 簡単に概念化した積雲対流プロセスを組 み込む方法を開発した。この方法は短時間で予測計算を して，短時間間隔で予測情報を更新することを念頭に置 いているために，非常に簡便な方法でレーダ観測情報を 取り込む. 本研究では，その手法を夏季の積乱雲の事例 に適用した。 2 章で積雲対流に対する物理的予測での データ同化の諸問題を整理したうえで，3章で積乱雲の 
観測データ，4章で手法と予測計算の設計について解説 する. そして，5章で一つの事例に適用した予測結果を 示す.

\section{2. 積雲対流に対するデータ同化の諸問題}

物理的予測では，観測データを同化することによって， シミュレーションの初期值を作成し積分計算を行う。こ のデータ同化手法については，近年目覚ましい発展がみ られる．特に4次元データ同化手法による気象レーダ データの同化は，近年盛んに研究されている.

Dowell et al. ${ }^{7)}$ や山口と中北8)などは, アンサンブルカ ルマンフィルタを用いたレーダ観測情報のデータ同化実 験を実施している.この手法は非常に有望であるが，事 前のアンサンブルシミュレーションの中に積乱雲が発生 するという情報が含まれていない場合に, 解析精度が落 ちる危険性がある，積雲対流などのように時間変化の激 しい現象の場合，短時間間隔での観測データの取り込み が必要とされる.

Kawabata et al. ${ }^{9}$ やSun et al. ${ }^{10)}$ は, 4次元変分法を用い てレーダ反射強度と動径風の情報を同化した．4次元変 分法では, データ同化ウインドウとよばれる短い期間が 設定され，その期間内の観測データが，前の時刻からの 予測計算結果と最適条件で結合される。観測情報は同化 ウインドウの初期時刻にモデルの物理空間上を上流伝搬 させられ，初期時刻で複数のデータが結合される. 非常 に有益な方法だが，計算に時間がかかるという難点があ るため, ナウキャストのように短時間で情報を出さなけ ればいけない場合に実装するのは容易ではない。

Sun et al. ${ }^{10)}$ は1〜6時間先までの予測スコアの評価を行 い，1２時間先では，動径風よりも反射強度を同化した 場合のほうが，スコアが高くなることが示した。 このこ とは，近未来の予測は，風などの大気環境場の観測情報 よりも，積雲対流に伴って強雨が発生したという事実の 情報が重要になることを示している，一方で，積雲対流 に関しては, 雲・降水の物理過程に含まれる力学系の強 い非線形性が，データ同化を難解にしている．この強い 非線形性によって，例えば，あるレーダ反射強度の観測 のデータ同化に対して，それに対応する積雲対流構造が 一つに決まらないという，解の多重性をもたらす。これ を回避するためには, 水物質の構造だけでなく, 対流内 の気流（3成分）の3次元構造，周辺大気の熱力学構造な どを同時に観測しなければならない。これに加えて，降 水域と非降水域間での, 気流観測の不連続性を解消させ ることが求められ，観測データへの要求は難度が高い． 計算能力や観測データの問題もあり, 多くの数值予報で は，初期值に積雲対流の構造が正しく埋め込まれていな い. 個々の積雲対流の構造を表現するのではなく, メソ $\beta$ スケール (20〜 200km) の大気構造を精度よく表現す
ることに主眼が置かれる.メソ $\beta$ スケールの大気構造が 精度よく表現されていれば, 最初の積雲対流の位置など は正しくなくても，2〜5時間程度先のメソ $\beta$ スケールの 降水の特徵の再現性はよくなると期待できる.

Sokol et al. ${ }^{11}$ は, ナッジングを用いてモデル計算の水 蒸気量をレーダ観測から近似的に推定し，その水蒸気量 を同化する手法を適用した，仮に，降雨強度観測をモデ ル大気中の水物質量に変換した場合, その水物質は, 蒸 発しながら落下し，下降流を形成し，消散するだけであ る.これは, 積乱雲の構造をデータ同化で再現すること にはならないため, 積乱雲の発生に伴う, それ以後の降 雨の変動によい影響を与えるとは限らない. つまり, レーダ観測から積乱雲内部の熱力学的構造をデータ同化 によって再現することが重要となる.

仮に，3次元変分法などのデータ同化システムを考え る. 観測された物理量と他の熱力学量は, 背景誤差共分 散行列に含まれる相関構造によって再現される。しかし， 例えば，水物質量に対して鉛直流の相関は低く，上昇流 なのか下降流なのかは一意に決まらない。つまり，相関 構造だけで積乱雲の構造を観測データから作り出すこと は難しく, 相関構造を利用したナッジングを設計したと しても同様の問題を抱える. そこで，強雨が観測された 時，水物質が生成されたという観測情報を上流に伝搬さ せ，その原因となるソースを置く方法を考える. この方 法は4次元変分法データ同化システムの考え方である. この手法を導入するには，モデルの時間発展の随伴演算 子が必要であり, 開発には多大な労力を要する。しかし, この随伴演算を近似的に扱うことで，簡便な同化システ ムを構築することが可能となる．近似化した簡便な随伴 演算効果については4章で説明寸る. 本研究でも基本的 にナッジングによる簡便なデータ同化を行うが，近似化 随伴演算によって上流伝搬させられた積雲対流のソース の情報が疑似観測として同化される仕組みである.

\section{3. 積乱雲の観測データ}

2013年9月 2日に埼玉・千葉県でF2クラスの竜巻が観測 された $\left(\right.$ 気象庁 $\left.{ }^{12}\right)$ ，この竜巻を発生させた積乱雲はスー パーセルと呼ばれる回転する積乱雲であった. 図 1 と図 2 は，それぞれ竜巻発生時刻における気象庁の天気図と レーダ画像を示している. 埼玉・千葉・茨城県境付近に 強い降水強度のセル状降水システムが形成されている. この降水システムは北東方向の走向の複数の降水セルで 構成されているため, 複数の積乱雲が集団化して観測さ れていると考えられる. 関東域は停滞前線の南側に位置 し, 大気の成層状態は不安定であった. 本研究では, こ の積乱雲の事例を対象として調査した.

データ同化実験で用いる観測データは，気象庁のレー ダ観測データであるが，ここでは非常に簡便な2次元の 
降雨強度分布データを用いる. 今回は, 気象庁のホーム ページの画像ファイルを代表值に変換して，これを観測 データとしている．降雨強度值そのものをデータ同化す るわけではないため, 悪影響はほとんどない.

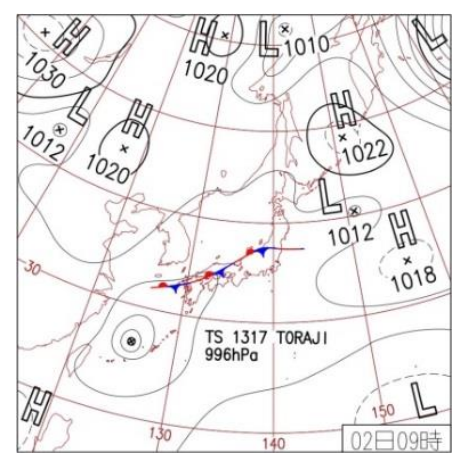

図-1 2013年9月2日9時（日本標準時）の天気図。気象庁ホー ムページより.

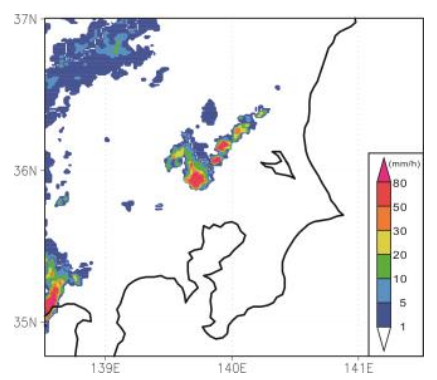

図-2 2013年9月2日13:10の関東域の合成レーダ画像. 気象庁 ホームページの画像を修正したもの.

\section{4. 大気モデルと計算設計}

本研究で用いた大気の物理モデルは名古屋大学で開発 された雲解像非静力学大気モデルCReSS (Cloud-resolving Storm Simulator; Tsuboki and Sakakibara $\left.{ }^{13}\right)$ である. 雲や雨 雪などの水物質を陽に計算することができる．実験は， 気象庁MSMやMGDSSTデータを初期・側面境界条件に 用いた数值シミュレーションを実施した. 実験設定の概 要を表-1に示寸．個々の積乱雲を計算上概ね再現可能な 設定になっている. 積乱雲は, 単独もしくは複数の積雲 対流（セル状の上昇流のコアとそれに付随する鉛直対流） で構成されている. 個々の積雲刘流を精度よく解像する には，500m以下の解像度で数值実験を行う必要がある が，短い時間で計算を終了させるための現時点での最良

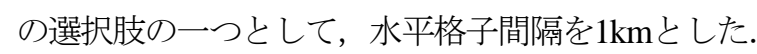

初期時刻を12:00とした実験では，観測されたような 積乱雲群を再現することはできなかった（詳細後述）。 そこで，気象庁のレーダ観測データを同化し，2時間程 度先までを予測する計算を10分ごとに更新する予報と解 析のサイクルシステムを構築した. データ同化は30分の ウインドウ期間で行い，それ以後は予測計算を行う。こ の予報と解析のサイクルについて, 図-3に概要を示す. まず，(a)前時刻からの予測を踏まえ，同化ウインドウ期 間にある観測をナッジングによって同化する．同化ウイ ンドウの途中の值は, (b)の次の(10分後)サイクルの同化 一と引き継がれ，予報の更新は連続して実施される.

この研究で用いているデータ同化システムでは, 降雨 強度や水物質量を直接同化しているわけではない。図-4 に積雲対流の進化とレーダ反射強度の関係についての概 念図を示す，積雲対流に伴う降雨は，積雲対流発生の結 果として, 進化の後半に観測されるものである. その概 念を踏まえ, 本研究では, 強雨が生じたという結果の情 報をもとに, 強雨を生成させる積雲対流の初期構造を疑 似的な観測と寸る。これは, 積雲対流の時間発展の随伴 演算を簡便な方法で近似することに相当する. 雲解像モ デル内に積雲対流を人為的に生成する場合，さまざまな 人為的擾乱が置かれる. 温位擾乱や収束などを置く研究 があるが，この中で下層を加湿する手法(Turpeinen and Yau $\left.{ }^{14)}\right)$ を参考にした。 つまり, 強雨観測の情報から, 観測よりも前の時刻の上流側下層の大気の水蒸気量を増 加させる疑似観測データを作成し，それをナッジングで 同化する，下層が十分に飽和していれば，対流抑制 (CIN; Convective inhibition)はゼロになるため, ほんのわ ずかな衝撃があれば, 積雲対流が生成される.

ナッジングでは, 弱い過飽和状態（今回の実験では相 対湿度（RH）を101\%）に強制させた. 10分前のサイク ルでの計算結果から温度や気圧などの第一推定值を求め, その状態に対する相対湿度 $101 \%$ で水蒸気混合比を見 積もり，これを疑似観測データとした。 また，自由対流 高度(LFC)を少し超えた高度 $(\mathrm{LFC}+\Delta \mathrm{z}$; 今回の実験では LFCの上空500mとした）までの下層大気を加湿した. 弱 い過飽和にしているのは，水蒸気を十分に凝結させ，か つ小さな衝撃を生じさせるためである，また，LFCを超 えて上空まで加湿しているのは, せっかく生じた積雲対 流に伴う上昇気流が，LFCより上空の乾燥した空気の工 ントレイメントに阻害されて消散するのを防ぐ効果を考

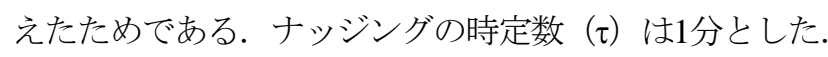
時定数が長い場合, 積雲対流に伴う降水が弱かったり, 遅れて出現したため, 本実験ではこの值に固定した.

RH， $\Delta \mathrm{z}$ を変えると予測結果は変わり，精度はてにも依存 するため，チューニングする必要がある（RH， $\Delta \mathrm{z}$ は大 きすぎてはいけない）。この研究では, 降雨強度 $10 \mathrm{~mm} / \mathrm{h}$ 積雲刘流に伴う降水之仮定した（図-7につい ては $20 \mathrm{~mm} / \mathrm{h}$ も検証）。それよりも強い降水がある領域 を上流側に伝搬させ，その下層を加湿する. 弱い降水域 は, 層状性降水之仮定した。 層状性降水は, 積雲対流に よって直接生成されるものではないと仮定して，上流の 下層加湿は行っていない. なお，降雨域の形状と上流下 層加湿を行う領域の水平方向の形状が同じである必然性 はないが，本研究では加湿域形状に関するモデル化は 行っていない，なお，下層加湿によって鉛直安定度がよ り不安定化する効果があるため, 観測される積乱雲より 
も強く再現してしまう可能性があるが，この問題は今後 の課題とする.

移動ベクトルは，レーダエコーの移動から求める。本 事例では，周辺の移動ベクトルは，北東方向に約 $9.5 \mathrm{~m} / \mathrm{s}$ と見積もられた．移動ベクトルは時空間的に変化するが, 本研究では，短い時間の狭い領域のみを解析対象として いるため，この值を固定した。

表-1 大気モデルおよびそれを用いた予測実験システムの設定

\begin{tabular}{cc}
\hline 大気モデル & CReSS (version 3.4.3) \\
\hline 領域 (水平格子数) & 関東域 $(250 \times 224)$ \\
鈆直格子数 & 33 層 \\
水平解像度 & $1 \mathrm{~km}$ \\
\hline 同化ウインドウ & 30 分 \\
予報・解析時間間隔 & 10 分更新 \\
予報 & 2時間 \\
\hline 初期・側面境界条件 & 気象宁MSM \\
海面境界条件 & 気象宁MGSST
\end{tabular}

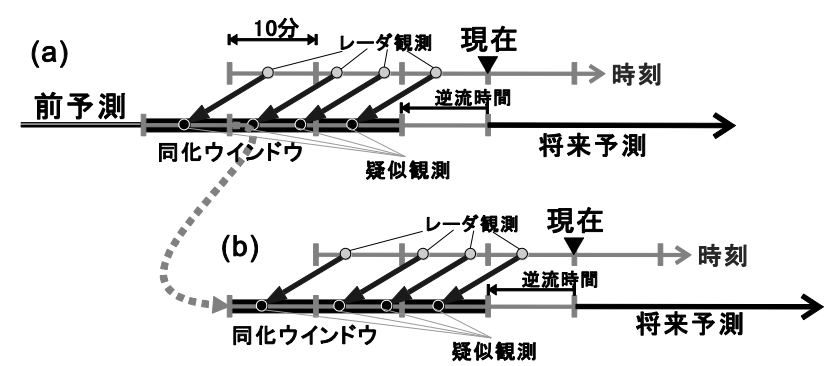

図-3 予報・解析サイクルの設計概念図. (a)のサイクルの後に, (b)のサイクルへと続く.図中の疑似観測とは，レーダ観測から 上流下層の大気の水蒸気量を増加させることを意味する．疑似 観測は，レーダ観測から時間的に遡って作成される（逆流）. 逆流時間を10分とした場合のイメージ図になっている.

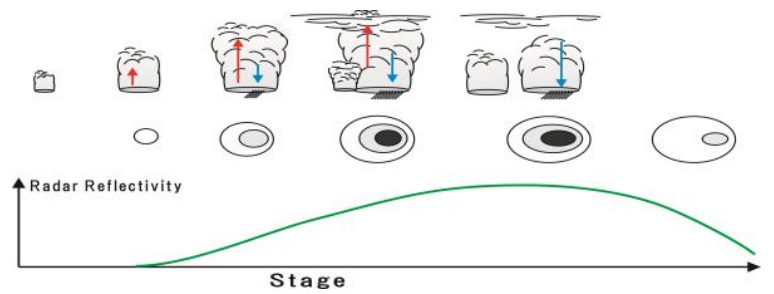

図-4 積雲対流の内部構造とレーダ反射強度の時間変化の概念 図. 赤矢印は上昇気流, 青矢印は下降気流. ○印はエコー分布 のイメージである.

\section{5. 結果}

図-5に開発したシステムを用いて予測された降雨強度 （地上）とレーダ観測データによる降雨強度の比較を示 している. 図-5bは，観測された複数の孤立積乱雲（図5a）は，特別な同化なしに再現することはできない事例 であったことを示している. 図-5c〜図-5gは，レーダエ コーを上流側に逆流（上流伝搬）させる時間を 00 分〜 40
分の間で10分毎に変化させ，再現させた降水の分布を示 している.この図はリードタイム00分で作図したもので ある.このリードタイムとは, 図-3の「現在」からどの くらい先の未来の時刻かを示したものである. なお，同 化ウインドウの末端時刻から逆流時間を足すと現在にな る. 図-5の対象時刻はいずれも竜巻が観測された時刻の 1時間前に相当する13:10となっている. 赤丸で示された 積乱雲に着目する. 逆流00分の下層加湿では，この積乱 雲に伴う強雨域を再現することはできていない. 富士山 周辺に強雨域が再現されているが，予報と解析のサイク ルを繰り返した結果発生したものである. 一方，赤丸の 積乱雲は，この時刻に発生してまだ十分な時間がたって いないため，予報と解析のサイクルを組んでも，逆流時 間 00 分では積乱雲は発生しない。一方，逆流時間を 10 ,

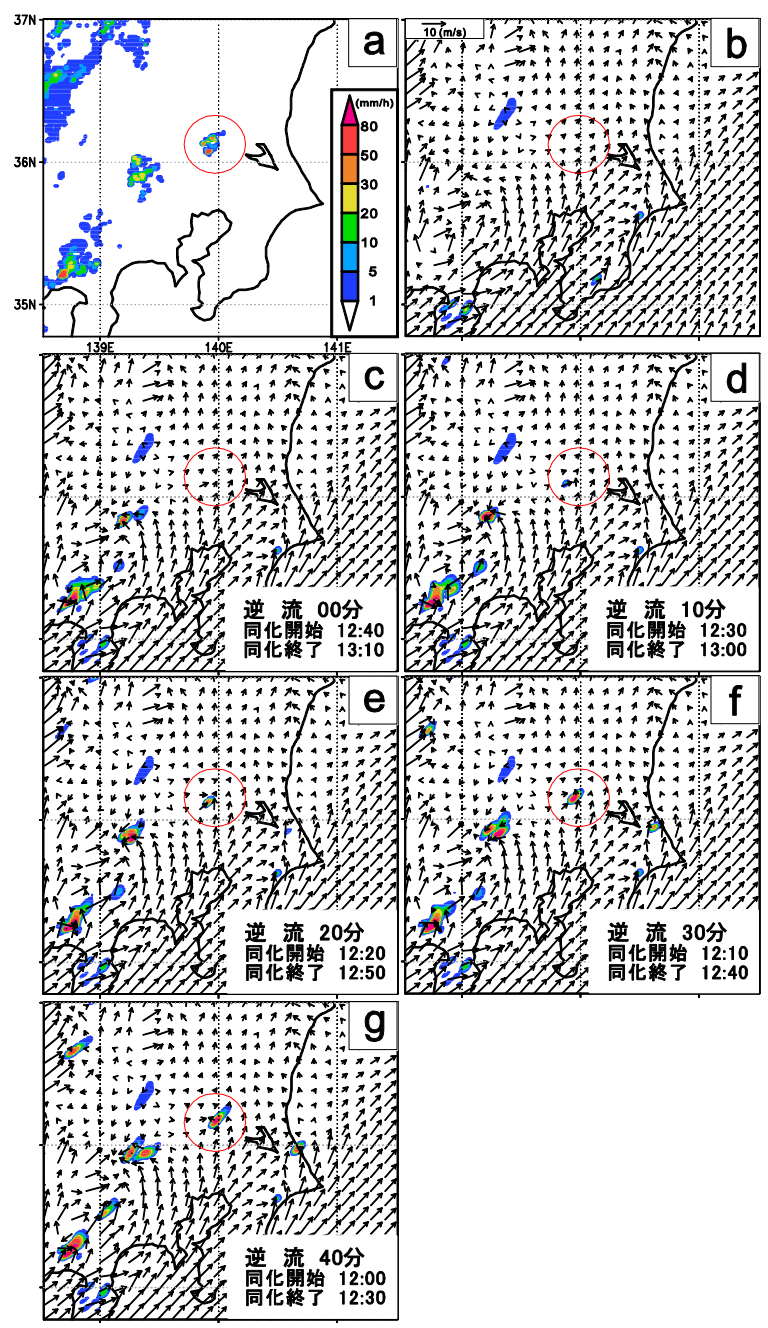

図-5 (a) 13:10の降水強度の観測と，(b) レーダデータの同 化を行っていない場合の同時刻の予報值（計算初期時刻 12:00）。(c)-(i)は, 図-3の予報・解析サイクルでレーダデー タを同化した場合の13:10の予測值で，00分〜40分までの10 分毎の逆流時間（上流伝搬時間）の設定での予測值. カ ラーは降水強度分布で, 矢羽はモデル最下層（地上 $70 \mathrm{~m}$ ) の風速分布. 図中の「同化開始」「同化終了」は，その予 報における同化ウインドウの始点と末端時刻を意味する. 
20, 30, 40分と伸ばしていくと, 赤丸の積乱雲に伴う強雨 がシミュレーション結果に現れてくる. 特に逆流 30,40 分の降水分布は，観測のそれと比べても非常によく似て いる.これは，強雨を検出した場合に，その強雨をもた らす積雲対流が，30～40分前の下層加湿によって発生し たことを意味している。

次に,リードタイムを変えた場合に，積雲対流の予測
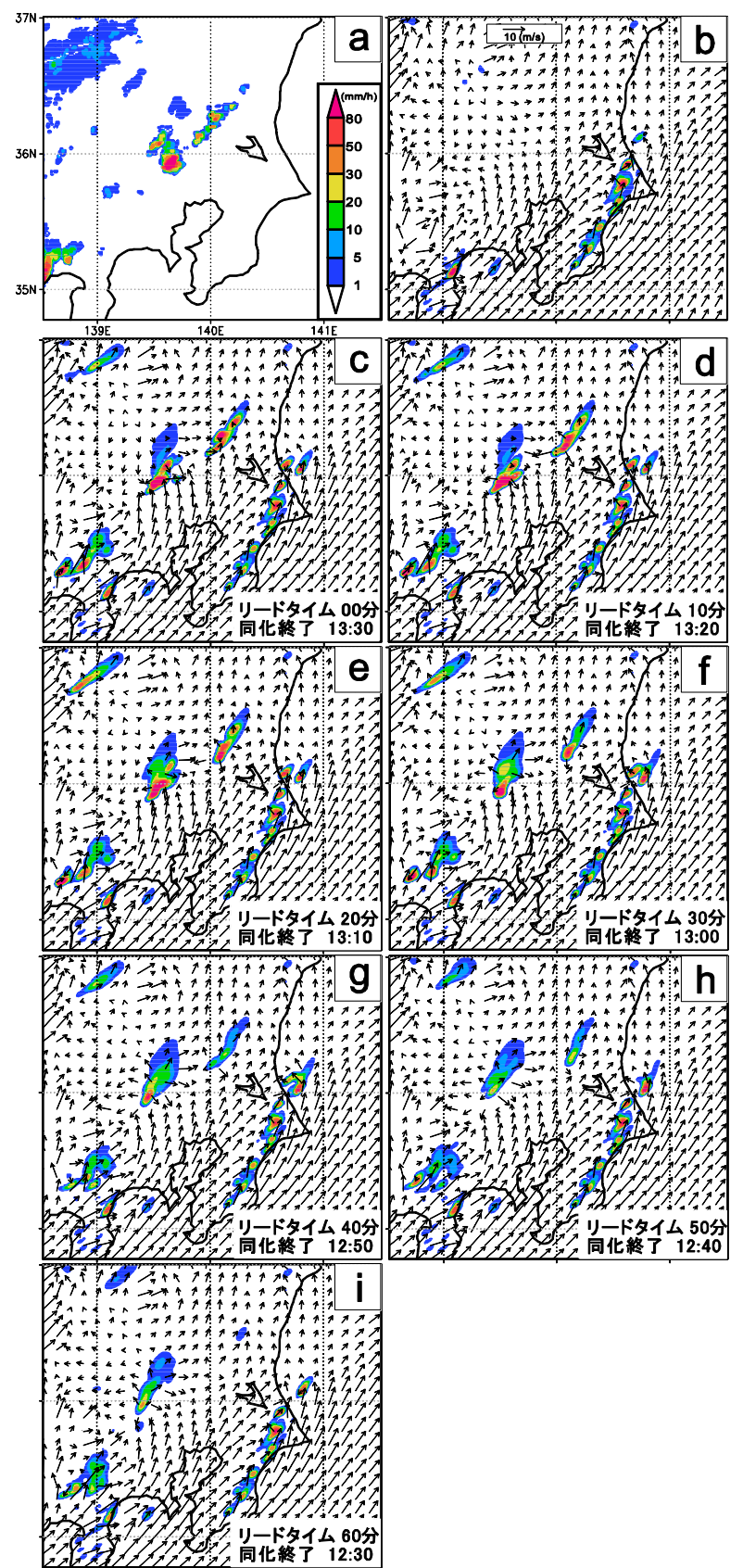

図-6 (a) 14:00の降水強度の観測と, (b) レーダデータの同化 を行っていない場合の同時刻の予報值（計算初期時刻

12:00） . (c)-(i)は, 図-3の予報・解析サイクルでレーダデータ を同化した場合の14:00の予測值で，00分～60分までの10分毎 のリードタイムの設定での予測值. 逆流時間は30分で固定. カラーは降水強度分布で, 矢羽はモデル最下層の風速分布. 図中の「同化終了」は，その予報における同化ウインドウの 末端時刻を意味する. 図-3の「現在」はその30分後である.
可能性がどの程度変化するかを調べた（図-6）。時刻は 14:00とした。逆流時間は30分で固定した.リードタイ ム00分の場合，同化ウィンドウの末端時刻は，対象時刻 の30分前になる. リードタイムを00分から60分まで変化 させると, 埼玉・千葉・茨城県境付近に走向が南西から 北東に並ぶ積乱雲群の再現性が徐々に落ちることがわか る.リードタイム60分では，北東側の積乱雲が全く再現 できていないことがわかる．積乱雲の振る舞いは，わず かな誤差が急速に時間発展する, 強い非線形系の現象で あるために，予測精度の急激な落ち込みを避けることは できない. 図-6は，もう一つ重要なポイントを示してい る.千葉県付近に，観測には見られない南西から北東の 走向を持つ積乱雲群が再現されている. 開発した手法で 積乱雲を生成することができるが，消滅させることは考 慮していない. これらの修正には，他のスキームの導入 が必要となる。

困-7に，スレッドスコアを示す。このスコアはリード タイ $\Delta 00,30,60$ 分, 降雨強度 $10,20,30 \mathrm{~mm} / \mathrm{h}$ 以上の降雨 の有無を調査したものであり，時空間の位置ずれを考慮 したスコアになっている，具体的には，水平方向に $5 \mathrm{~km}$, 時間方向に10分の位置ずれがあっても, 閾值以上の降雨 があれば，有りとしてカウントされる.この図は，リー ドタイム30分（60分）では逆流時間20分（10２0分）で 精度が最も高いことを示している. 上流側に積雲対流の 発生の情報を伝搬させることで，予測精度が明確に向上 していることを示している. 一方, リードタイム 00 分で は逆流時間が30分程度で精度が最も高い! リードタイム 00分で逆流時間が短い場合は，降水が十分に生成されて いないことが原因している。また，この精度は逆流させ る際に用いる移動ベクトルの精度にも依存していると推 定される. 本実験では，移動ベクトルは空間的時間的に 一定值を用いた。しかし，実際は，移動ベクトルは空間 的にも時間的にも変動するはずである。このわずかな䛊 差が予報時間を延ばすと時間発展してしまい，長い逆流 時間による予測計算結果の精度は，より短い逆流時間の
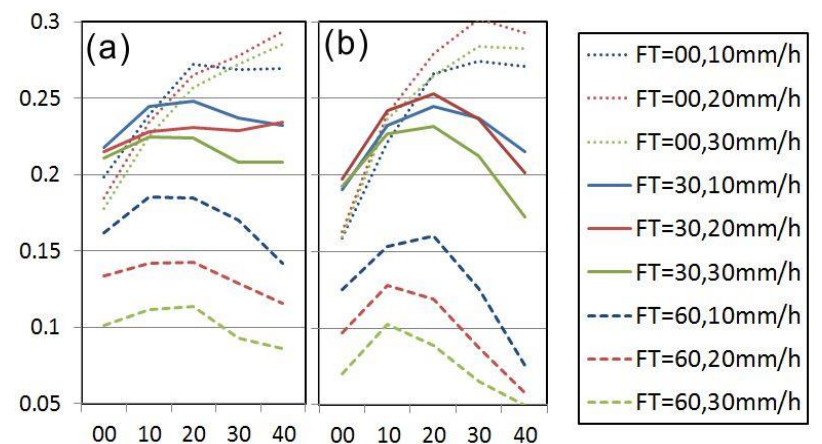

図-7 00,30,60分のリードタイム $(\mathrm{FT}=) ， 10,20,30 \mathrm{~mm} / \mathrm{h}$ の検 証のための降水強度の閾值で見積もったスレットスコアを00 〜40分の逆流時間 (横軸) で比較したもの. 時間10分, 空間 $5 \mathrm{~km}$ の位置ずれを許容して見積もったスコアである. (a)は加 湿する降水強度の閾值を $10 \mathrm{~mm} / \mathrm{h},(\mathrm{b})$ は $20 \mathrm{~mm} / \mathrm{h}$ とした結果. 
精度よりも劣ってしまうと推定される.

本事例は，埼玉・千葉県に竜巻を発生させたスーパー セル型積乱雲であったことが報告されている、スーパー セル型の積乱雲では，積乱雲内に大きな正の鉛直渦度領 域を伴っていると推定される. 図-8は，14:10での降雨強 度分布と下層での鉛直渦度や温度などの分布を示してい る. 積乱雲の南側にシアラインがあり, 積乱雲の南東端 に強い正の鉛直渦度を伴っており，この渦（メソサイク ロン）が竜巻発生に関連していたことが示唆される。こ の情報は, 強雨のみならず, 突風現象の発生予測にも有 効になりえることを示唆している.

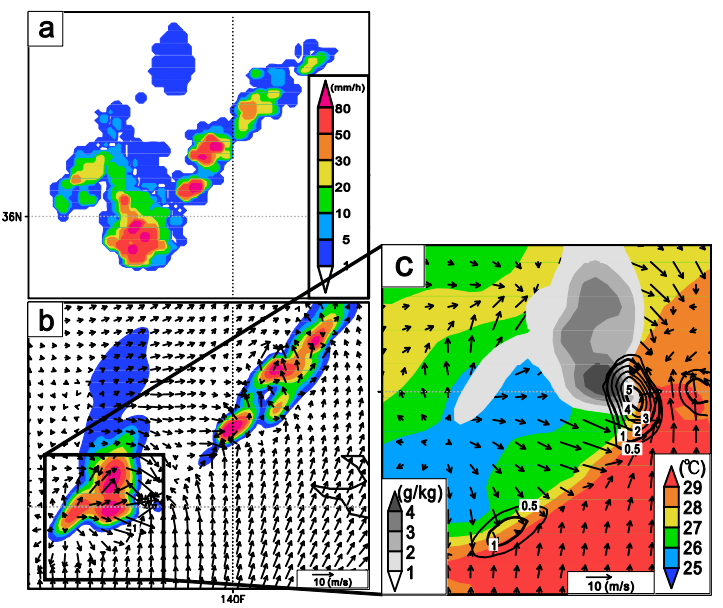

図-8 (a)14:10の観測された降雨強度と(b)同時刻に予報・解析 サイクルで再現された降水と風速の分布（モデル最下層; 高度 70m）。リードタイムは00分とした. (c)は(b)の積乱雲を拡大し た高度70mの分布図で, 雨水混合比 (グレースケール), 温度 （カラー），風速（矢羽），鉛直渦度（黒線; 単位は $10^{-3} \mathrm{~s}^{-1}$ ）。

\section{6. まとめ}

物理的予測手法で強雨を予測するシステムを開発し， 2013年9月2日に埼玉・千葉県でF2クラスの竜巻を発生さ せた積乱雲およびその周辺の積乱雲の事例に適用した. この手法では，レーダ観測から得られる降雨域の情報を 上流側に伝搬させ，前の時刻の上流位置の下層大気を飽 和させることで, 積乱雲を発生させた. この方法は, 4 次元変分法データ同化システムを非常に簡便な方法で近 似したことに相当する．その結果，約20分の逆流で積乱 雲にともなう強雨の再現性が著しく向上したことが示さ れた.

この手法には4点の課題が残っている。i) 不自然に発 生した強雨域の消滅手法の開発，ii）レーダエコーの時 間外挿とのブレンディングによる降水予測精度の向上 （層状性降水である弱雨はここで結合される），iii）積 乱雲の発生位置の同定の高精度化，iv）疑似観測として 与える積雲刘流の初期構造の検討である.さらなる研究 が期待される.
謝辞 : 本研究は, JSTのテニュアトラック普及定着事業 (若月泰孝) の支援を得た，本論文作成において，筑波 大学大学院地球科学専攻の野澤知弘さんと筑波大学地球 学類の並木彩さんの協力を得た. 京都大学防災研究所の 中北英一教授をはじめと寸る科研費研究「最新型偏波 レーダーとビデオゾンデの同期集中観測と水災害軽減に 向けた総合的基礎研究」のメンバーの助言もいただいた.

\section{参考文献}

1) 斉藤和雄, 牧原康隆: 降水現象の予報高度化の技術. 天気, Vol. 54(7), pp. 622-631, 2007.

2) 加藤敦, 真木雅之, 岩波越, 三隅良平, 前坂剛: Xバンドマル チパラメータレーダ情報と気象庁レーダ情報を用いた降水 ナウキャスト. 水文・水資源学会誌, Vol. 22, No. 5, pp. 372$385,2009$.

3) 吉野純, 野村俊夫, 安田孝志: 降水量予測の精度向上のため の位置誤差修正法に基づくレーダーデータ同化システムの 開発. 水工学論文集, Vol. 53, pp. 379-384, 2009.

4) 飯田潤士, 安藤文香, 吉野純, 安田孝志: 降雨域の複雑変化 を画像解析的に取り込んだ強雨の 1 時間予測. 土木学会論 文集B1(水工学), Vol.68, No.4, pp385-390, 2012.

5) 気象庁: 気象業務はいま2014. 研精堂印刷侏式会社, 2014.

6) Kober, K., Craig, G. C., Keil, C., and Dörnbrack, A.: Blending a probabilistic nowcasting method with a high-resolution numerical weather prediction ensemble for convective precipitation forecasts. Q. J. Roy. Meteor. Soc., Vol. 138, pp. 755-768, 2012.

7) Dowell, D. C., Wicker, L. J., and Snyder, C.: Ensemble Kalman Filter Assimilation of Radar Observations of the 8 May 2003 Oklahoma City Supercell: Influences of Reflectivity Observations on Storm-Scale Analyses. Mon. Wea. Rev., Vol. 139, pp. 272-294, 2011.

8) 山口弘誠, 中北英一: アンサンブルカルマンフィルタを用い たドップラーレーダー情報の4次元同化設計. 水工学論文集, Vol. 52, pp343-348, 2008.

9) Kawabata, T., Seko, H., Saito, K., Kuroda T., Tamiya K., Tsuyuki, T., Honda, Y., and Wakazuki, Y.: An Assimilation Experiment of the Nerima Heavy Rainfall with a Cloud-Resolving Nonhydrostatic 4-Dimensional Variational Data Assimilation System. Journal of the Meteorological Society of Japan, Vol. 85, pp. 255-276, 2007.

10) Sun, J., and Wang, H.: Radar Data Assimilation with WRF 4D-Var. Part2: Comparison with 3D-Var for a Squall Line over the U.S. Great Plains. Mon. Wea. Rev., Vol. 141, pp. 2245-2264, 2013.

11) Sokol, Z.: Assimilation of extrapolated radar reflectivity into a NWP model and its impact on a precipitation forecast at high resolution. Atmos. Res., Vol. 100, pp.201-212, 2011.

12) 気象庁: 現地災害調查速報: 平成25年9月 2 日に埼玉県さいた ま市，越谷市，北葛飾郡松伏町，千葉県野田市，茨城県坂 東市で発生した突風について, 2013.

13) Tsuboki, K. and Sakakibara, A.: Cloud Resolving Storm Simulator User's Guide, Second Edition, 2001.

14) Turpeinen, O. and Yau, M.K.: Comparisons of Results from a Three-Dimensional Cloud Model with Statistics of Radar Echoes on Day 261 of GATE. Mon. Wea. Rev., Vol. 109, pp.1495-1511, 1981.

(2014. 9. 30受付) 